\title{
Perdebatan Empiris : Prinsip Metode Kualitatif dan Kuantitatif Untuk Penelitian Sosial Ekonomi
}

\section{Puspa Dewi Yulianty ${ }^{1}$}

puspadewi@umc.ac.id

\section{Dosen FE Universitas Muhammadiyah Cirebon \\ Ali Jufri \\ ali.jufri@umc.ac.id \\ Dosen FE Universitas Muhammadiyah Cirebon}

\begin{abstract}
Abstrak
Di era distrupsi teknologi sekarang perdebatan tentang metode mana yang terbaik dalam penelitian masih menjadi sebuah perdebatan sengit. Perdebatan yang saling menonjolkan kekuatan dan mencari kelemahan selalu menjadi hal yang menarik untuk kita analisis. Hal yang paling mendasar dalam melakukan penelitian adalah mengikuti aturan yang benar dengan prinsip paradigma dan metodologi yang dipilih sesuai dengan masalah penelitian yang muncul. Metodologi ilmiah adalah alat yang sangat penting bagi pengetahuan tentang metode yang digunakan dalam penjabaran dokumen ilmiah, seperti manuskrip, disertasi, atau karya menyelesaikan tugas pada universitas. Metodologi ilmiah mencakup studi tentang metode atau instrumen yang diperlukan untuk penjabaran suatu karya ilmiah. Tulisan ini menggunakan studi literatur yang relevan dengan menggunakan artikel-artikel yang saling terkait dalam menjabarkan perdebatan prinsip penelitin menggunakan metode kualitatif atau kuantitatif. Kami berharap tulisan ini memberikan pemahaman yang komprehensif dalam memandu penggunaan metode penelitian yang benar.
\end{abstract}

Kata Kunci : Metode Kualitatif dan Metode Kuantitatif

\section{Pendahuluan}

Flanagan (2013) dikutip oleh Queirós, et.all, (2017) mengklaim bahwa metode ilmiah adalah alat yang paling kuat untuk menemukan kebenaran tentang dunia, mengeksplorasi teori-teori baru dan melakukan validasi empiris mereka. Oleh karena itu, penelitian ilmiah adalah proses melakukan penyelidikan yang sistematis dan intensif, yang bertujuan untuk menemukan dan menafsirkan fakta-fakta yang dimasukkan dalam realitas tertentu. 
Sehubungan dengan pendekatannya, penelitian ilmiah dapat bersifat kualitatif atau kuantitatif.

Penelitian kualitatif memperdalam pemahaman masalah yang diberikan. Dalam penelitian kualitatif, peneliti adalah subjek dan objek penelitiannya. Tujuan dari metodologi kualitatif adalah untuk menghasilkan informasi yang mendalam dan ilustrasi untuk memahami berbagai dimensi masalah yang sedang dianalisis. Karena itu, penelitian kualitatif berkaitan dengan aspek-aspek realitas yang tidak mungkin terjadi dikuantifikasi, dengan fokus pada pemahaman dan penjelasan tentang dinamika hubungan sosial. Maxwell (2013) dikutip oleh Queirós, et.all, (2017) menganjurkan bahwa penelitian kualitatif bekerja dengan makna yang luas, motif, aspirasi, kepercayaan, nilai-nilai dan sikap, yang sesuai dengan ruang yang lebih dalam dari hubungan, proses dan fenomena yang tidak dapat direduksi menjadi operasionalisasi variabel.

Sedangkan dalam studi kuantitatif, peneliti menggunakan kuesioner standar atau eksperimen untuk mengumpulkan data numerik. Penelitian kuantitatif dilakukan dalam lingkungan yang lebih terstruktur yang memungkinkan peneliti untuk mengendalikan variabel studi, menentukan hubungan antara variabel dan hasil. Penelitian kuantitatif melibatkan pengembangan hipotesis, deskripsi hasil yang diantisipasi, hubungan, atau hasil yang diharapkan dari pertanyaan yang diteliti (Polit \& Beck, 2012; Rutberg \& Bouikidis, 2018).

Peneliti menggunakan pertanyaan terbuka dan mewawancarai subjek dengan cara semi-terstruktur. Wawancara sering dilakukan dalam suasana alami peserta atau lingkungan yang tenang, seperti ruang konferensi. Metodologi penelitian kualitatif sering digunakan ketika masalah tidak dipahami dengan baik dan ada keinginan yang ada untuk mengeksplorasi masalah secara menyeluruh. Biasanya, narasi yang kaya dari wawancara partisipan dihasilkan dan kemudian dianalisis dalam penelitian kualitatif sebagai upaya untuk menjawab pertanyaan penelitian. Banyak pertanyaan akan digunakan untuk mengungkap masalah dan mengatasinya secara komprehensif (Polit \& Beck, 2014; Rutberg \& Bouikidis, 2018).

Dalam pelitian kualitatif terdapat beberapa jenis-jenis penelitian antara lain etnografi, fenomenologi, grounded theory, penelitian sejarah, dan studi kasus (Polit \& Beck, 2014; Rutberg \& Bouikidis, 2018). Etnografi mengungkapkan cara budaya didefinisikan, perilaku yang terkait dengan budaya, dan bagaimana budaya dipahami. Desain etnografi memungkinkan peneliti untuk menyelidiki makna bersama yang memengaruhi perilaku kelompok (Polit \& Beck, 2012; Rutberg \& Bouikidis, 2018). 
Fenomenologi digunakan untuk menyelidiki pengalaman hidup seseorang dan mengungkap makna dari pengalaman ini (Polit \& Beck, 2012; Rutberg \& Bouikidis, 2018). Saat memilih desain penelitian kualitatif, ingatlah atribut uniknya. Metodologi penelitian kualitatif dapat melibatkan berbagai cara pengumpulan data untuk lebih memahami masalah, seperti wawancara dan pengamatan (Polit \& Beck, 2012). Selanjutnya, penelitian kualitatif fleksibel dan beradaptasi dengan informasi baru berdasarkan data yang dikumpulkan, memberikan perspektif holistik pada topik, dan memungkinkan peneliti untuk menjadi tertanam dalam penyelidikan. Keputusan untuk memilih metodologi kualitatif membutuhkan beberapa pertimbangan, sejumlah besar perencanaan (seperti desain penelitian mana yang paling sesuai dengan studi, waktu yang diperlukan untuk mencurahkan studi, rencana pengumpulan data, dan sumber daya yang tersedia untuk mengumpulkan data) dan akhirnya, refleksi diri pada setiap anggapan pribadi dan bias terhadap topik (Polit \& Beck, 2014; Rutberg \& Bouikidis, 2018).

Memilih populasi sampel dalam penelitian kualitatif dimulai dengan mengidentifikasi kelayakan untuk berpartisipasi dalam penelitian berdasarkan pertanyaan penelitian. Peserta perlu memiliki paparan atau pengalaman dengan konten yang diselidiki. Wawancara menyeluruh akan mengungkap pertemuan yang dimiliki peserta dengan pertanyaan atau pengalaman penelitian. Kemungkinan besar akan ada beberapa pertanyaan standar yang diajukan dari semua peserta dan pertanyaan berikutnya yang akan berkembang berdasarkan pengalaman / jawaban peserta. Dengan demikian, cenderung ada ukuran sampel kecil dengan volume tinggi data narasi yang perlu dianalisis dan ditafsirkan untuk mengidentifikasi tren yang dimaksudkan untuk menjawab pertanyaan penelitian (Polit \& Beck, 2014; Rutberg \& Bouikidis, 2018).

Berdasarkan pemaparan diatas dapat terlihat pola pemakaian metodologi yang benar dari kualitatif dan kuantitatif bisa diambil dari penejelasan di atas. Namun banyak penjelasan para peneliti yang menunjukkan bahwa perbedaan antara penelitian kualitatif dan kuantitatif tidak memenuhi kriteria untuk pembedaan yang sangat tepat untuk memisahkan bagianbagian penyusunnya dengan cara yang tidak tumpang tindih, jelas dan tidak ambigu. Sebagai contoh, salah satu bagian penyusun dalam penelitian kualitatif, mengandung banyak kecenderungan yang berpotensi kontradiktif yang membuat konsep penelitian kualitatif menjadi tidak stabil. Jika salah satu (atau keduanya) bagian dari perbedaan tidak stabil ini akan berkontribusi untuk membuat perbedaan tidak stabil yang kemungkinan akan berdampak negatif pada kemungkinan untuk membuat perbedaan dengan cara yang jelas dan tidak membingungkan. Selain itu, perbedaan yang tampak tidak memenuhi kriteria 
memisahkan bagian-bagiannya dengan cara yang tidak sesuai aturan dan cukup tumpang tindih. Bahkan, pendekatan penelitian kualitatif dan kualitatif ditemukan tumpang tindih ke tingkat yang cukup besar. Mengingat perbedaan itu tidak jelas dan dibuat dengan cara yang berbeda, banyak di antaranya kontroversial, tampaknya perbedaan itu berkontribusi pada penyebaran kebingungan daripada pemahaman yang lebih baik. (Allwood, 2012)

Selain itu, perbedaan antara pendekatan kualitatif dan kuantitatif bermasalah bukan hanya karena telah memunculkan sudut pandang yang bermasalah dan membingungkan yang dibahas di bagian utama artikel, tetapi juga karena mungkin terbukti membatasi pengembangan metode penelitian baru. Sebagai contoh, peneliti yang percaya bahwa hanya diperbolehkan mengembangkan metode baru dalam kerangka referensi yang diasumsikan dari masing-masing pendekatan kualitatif dan kuantitatif akan kehilangan peluang untuk kombinasi fitur yang bermanfaat yang dimiliki kedua pendekatan tersebut. Berdasarkan pemaparan di atas penulis berusaha menyajikan sudut pandang yang benar dalam memahami metode penelitian Kualitatif dan kuantitatif.

\section{Desain Penelitian}

Mengikuti metode yang ditetapkan (Bergstrom, van Winsen, dan Henriqson, 2015; Dorn, Shweiger, dan Albers, 2016; Skrzek-Lubasinska dan Szaban, 2018), kami menyajikan tinjauan literatur sistematis publikasi yang relevan mengenai perbandingan, paradigma dan metode kualitatif dengan kuantitatif. Tulisan ini diharapkan mampu memberikan pemahaman yang lebih baik dalam menggunakan operasi penelitian kualitatif maupun kuantitatif dengan prinsip yang benar.

\section{Kajian Teori}

\section{Metode Kualitatif}

Penelitian kualitatif adalah penting karena ini merupakan fokus utama dari bagian ini, tetapi ada tantangan untuk mendefinisikan istilah ini dengan jelas (Ritchie, Lewis, Nicholls, \& Ormston, 2013; Rahman, 2017), karena tidak memiliki teori atau paradigma maupun cara yang jelas. seperangkat metode atau praktik yang semata-mata miliknya sendiri (Denzin \& Lincoln, 2011; Rahman, 2017). Istilah ini juga melibatkan beragam metode dan pendekatan dalam berbagai subjek penelitian. Oleh karena itu, para penulis telah memberikan definisi penelitian kualitatif secara khusus. Strauss dan Corbin (1990, hal. 11) dikutip oleh Rahman (2017), misalnya, menyatakan bahwa, dengan istilah penelitian kualitatif, kami maksudkan 
segala jenis penelitian yang menghasilkan temuan yang tidak sampai pada prosedur statistik atau cara kuantifikasi lainnya. Penelitian kualitatif merujuk pada penelitian tentang kehidupan orang, pengalaman hidup, perilaku, emosi, dan perasaan serta tentang fungsi organisasi, gerakan sosial, fenomena budaya, dan interaksi antar negara. Ini berarti bahwa penelitian kualitatif tidak bersifat statistik dan menggabungkan banyak realitas.

\section{Keunggulan}

1. Pendekatan penelitian kualitatif menghasilkan deskripsi tebal (terperinci) tentang perasaan, pendapat, dan pengalaman peserta; dan menafsirkan makna tindakan mereka (Denzin, 1989; Rahman, 2017).

2. Pendekatan penelitian kualitatif (interpretivisme) secara holistik memahami pengalaman manusia dalam pengaturan tertentu. Denzin dan Lincoln (2002) dikutip Rahman (2017), misalnya, menyebutkan bahwa penelitian kualitatif adalah bidang interdisipliner yang mencakup berbagai sudut pandang epistemologis, metode penelitian, dan teknik interpretatif untuk memahami pengalaman manusia.

3. Pendekatan penelitian interpretivisme dianggap sebagai penelitian ideografi, studi kasus atau peristiwa individual (Kelin \& Myers, 1999; Rahman 2017); dan memiliki kemampuan untuk memahami suara, makna, dan acara orang yang berbeda. Jadi sumber pengetahuan dalam pendekatan ini adalah makna dari berbagai peristiwa (Richardson, 2012; Rahman, 2017).

4. Penelitian kualitatif mengakui para peneliti untuk menemukan pengalaman batin para peserta, dan untuk mencari tahu bagaimana makna dibentuk melalui dan dalam budaya (Corbin \& Strauss, 2008; Rahman, 2017).

5. Metode penelitian kualitatif seperti observasi partisipan, wawancara tidak terstruktur, observasi langsung, menggambarkan catatan yang paling umum digunakan untuk mengumpulkan data (Cohen, Manion, \& Morrison, 2011). Selama pengumpulan data, para peneliti berinteraksi dengan para peserta secara langsung seperti yang terjadi saat pengumpulan data melalui wawancara. Akibatnya, pengumpulan data bersifat subyektif dan terperinci.

6. Desain penelitian kualitatif (pendekatan interaktif) memiliki struktur yang fleksibel karena desain dapat dibangun dan direkonstruksi ke tingkat yang lebih besar (Maxwell, 2012; Rahman 2017). 


\section{Kelemahan}

1. Pendekatan penelitian kualitatif kadang-kadang meninggalkan sensitivitas kontekstual, dan lebih fokus pada makna dan pengalaman. (Silverman, 2010; Rahman, 2017) Pendekatan fenomenologis, misalnya, berupaya mengungkap, menafsirkan, dan memahami pengalaman para peserta (Wilson, 2014; Tuohy et al., 2013; Rahman, 2017).

2. Pembuat kebijakan dapat memberikan kredibilitas rendah untuk hasil dari pendekatan kualitatif. Sallee and Flood (2012) yang dikutip Rahman (2017) menemukan bahwa pemangku kepentingan sering menggunakan penelitian kuantitatif ketika penelitian dipanggil.

3. Metode penelitian, ukuran sampel yang lebih kecil menimbulkan masalah generalisasi bagi seluruh populasi penelitian (Harry \& Lipsky, 2014; Thompson, 2011; Rahman, 2017).

Tabel 1 Prinsip Utama Dari Model Kuantitatif

\begin{tabular}{|l|l|}
\hline $\begin{array}{l}\text { Apa asumsi mendasar tentang } \\
\text { pengalaman kita tentang dunia? }\end{array}$ & $\begin{array}{l}\text { Kita hanya dapat mengalami dunia sebagai } \\
\text { serangkaian persepsi yang terpisah }\end{array}$ \\
\hline $\begin{array}{l}\text { Apa asumsi metodologis yang } \\
\text { mendasarinya? }\end{array}$ & $\begin{array}{l}\text { Kita tidak dapat berasumsi, 'apriori', bahwa salah satu } \\
\text { persepsi kita sebenarnya terhubung di dunia nyata }\end{array}$ \\
\hline Karena itu, apa tugas metodologis yang & Untuk membangun koneksi yang kami anggap benar- \\
mendasarinya? & benar ada \\
\hline Bagaimana kita melakukan ini? & $\begin{array}{l}\text { Kita dapat menghitung fenomena tertentu dan tingkat } \\
\text { kejadian yang mereka miliki dengan fenomena lain }\end{array}$ \\
\hline Apa akar bahasa Latinnya? & 'Quanto' - berapa banyak? \\
\hline Secara praktis, apa yang harus kita miliki & Ukuran dasar yang cukup besar, kondisi yang \\
untuk mencapai ini? & terkendali, dan penerapan statistik yang benar \\
\hline
\end{tabular}

Sumber : Barnham (2016)

\section{Metode Kuantitatif}

Bryman (2012, hal. 35) dalam Rahman (2017) mendefinisikan penelitian kuantitatif sebagai strategi penelitian yang menekankan kuantifikasi dalam pengumpulan dan analisis data. Ini berarti penelitian kuantitatif menunjukkan sesuatu yang berjumlah. Metode penelitian ini mencoba menyelidiki jawaban atas pertanyaan yang dimulai dengan berapa banyak, berapa banyak, sampai sejauh mana (Rasinger, 2013; Rahman, 2017). 


\section{Keunggulan}

Temuan kuantitatif cenderung digeneralisasikan ke seluruh populasi atau sub-populasi karena melibatkan sampel yang lebih besar yang dipilih secara acak (Carr, 1994; Rahman, 2017). Selain pengambilan sampel, analisis data kurang memakan waktu karena menggunakan perangkat lunak statistik seperti SPSS (Connolly, 2007, Rahman, 2017). Kemudian, penelitian kuantitatif didasarkan pada paradigma positivism untuk mengukur variabel (Kauber, 1986; Rahman, 2017).

\section{Kekurangan}

Paradigma penelitian positivisme mengesampingkan makna umum dari fenomena sosial (Denzin \& Lincoln, 1998, Rahman, 2017). Ia juga gagal memastikan makna dan penjelasan yang mendasarinya lebih dalam. Keterbatasan lain dari penelitian kuantitatif adalah bahwa positivisme tidak dapat menjelaskan bagaimana realitas sosial dibentuk dan dipertahankan, atau bagaimana orang menafsirkan tindakan mereka dan orang lain (Blaikie, 2007; Rahman, 2017).

Kelemahan lebih lanjut dari pendekatan penelitian kuantitatif adalah bahwa ia memiliki kecenderungan mengambil snapshot dari suatu fenomena: Ia mengukur variabel pada saat tertentu dalam waktu, dan mengabaikan apakah foto itu terjadi untuk menangkap orang yang mencari yang terbaik atau yang tampak tidak teratur (Schofield, 2007; Rahman 2017). Meskipun kelemahan di atas ada dengan penelitian kuantitatif, sejumlah besar penelitian sedang dilakukan di arena pengujian dan penilaian bahasa dengan menggunakan metode dan pendekatan penelitian kuantitatif. Penilaian bahasa memiliki tradisi menggunakan prosedur psikometrik dan orientasi yang kuat dari metode penelitian kuantitatif yang berfokus pada validitas skor tes (Purpura, 2011). Selain itu, pengujian bahasa diperhitungkan sebagai pengukuran. Perlu dicatat bahwa fase psikometrik-struktural pengujian bahasa dilambangkan oleh Spolsky menekankan pada reliabilitas tes dan menetapkan konsep pengujian bahasa sebagai pengukuran (Morrow, 2012). Jadi, dari konsep ini, pengujian bahasa tampaknya bersifat kuantitatif daripada kualitatif. 
Tabel 2 Prinsip Utama Dari Model Kuantitatif

\begin{tabular}{|c|c|}
\hline $\begin{array}{l}\text { Apa asumsi mendasar tentang } \\
\text { nengalaman kita tentang dunia? }\end{array}$ & $\begin{array}{l}\text { Kita dapat mengalami dunia hanya sebagai kontinum } \\
\text { nersentual }\end{array}$ \\
\hline Apa asumsi metodologis yang & Kita dapat berasumsi, 'a priori', bahwa semua \\
\hline mendasarinya? & persepsi kita terhubung, dengan satu atau lain cara, \\
\hline Karena itu, apa tugas metodologis yang & $\begin{array}{l}\text { catu cama lain dan oleh larena itu hercifat relacional } \\
\text { Untuk menetapkan bagaimana para responden }\end{array}$ \\
\hline mendasarinya? & membagi pengalaman mereka tentang dunia melalui \\
\hline Bagaimana kita melakukan ini? & $\begin{array}{l}\text { 'nanilninn narcanci' maral_n } \\
\text { Kami mengidentifikasi bagaimana konsumen }\end{array}$ \\
\hline & membuat perbedaan dan membuat perbandingan di \\
\hline Apa akar bahasa Latinnya? & 'Qualis?' - seperti apa? \\
\hline $\begin{array}{l}\text { Secara praktis, apa yang harus kita miliki } \\
\text { untuk mencapai ini? }\end{array}$ & ? \\
\hline
\end{tabular}

Sumber : Barnham (2016)

\section{Paradigma}

1. Paradigma interpretiv / konstruktivis tumbuh dari filsafat fenomenologi Edmund Husserl dan studi Wilhelm Dilthey dan filsuf Jerman lainnya tentang pemahaman interpretatif yang disebut hermeneutika (Mertens, 2005, hal.12 mengutip Eichelberger, 1989; Mackenzie \& Knipe, 2006). Pendekatan penafsiran / konstruktivis untuk penelitian memiliki niat untuk memahami "dunia pengalaman manusia" (Cohen \& Manion, 1994, hal.36; Mackenzie \& Knipe, 2006), menunjukkan bahwa "realitas dibangun secara sosial" (Mertens, 2005, hal.12; Mackenzie \& Knipe, 2006). Peneliti interpretivist / konstruktivis cenderung mengandalkan "pandangan peserta tentang situasi yang sedang dipelajari" (Creswell, 2003, hal.8; Mackenzie \& Knipe, 2006) dan mengakui dampak pada penelitian latar belakang dan pengalaman mereka sendiri. Konstruktivis umumnya tidak memulai dengan teori (seperti postpositivists) tetapi mereka "menghasilkan atau mengembangkan teori atau pola makna" (Creswell, 2003, p.9; Mackenzie \& Knipe, 2006) secara induktif selama proses penelitian. Peneliti konstruktivis kemungkinan besar bergantung pada metode pengumpulan data kualitatif dan analisis atau kombinasi metode kualitatif dan kuantitatif (metode campuran). Data kuantitatif dapat digunakan dengan cara, yang mendukung atau memperluas data kualitatif dan secara efektif memperdalam deskripsi.

2. Paradigma Transformative

Menurut Mertens (2005) yang dikutip oleh Mackenzie \& Knipe (2006) paradigma transformatif muncul selama 1980-an dan 1990-an sebagian karena ketidakpuasan terhadap paradigma dan praktik penelitian yang ada dan dominan, tetapi juga karena kesadaran bahwa banyak teori sosiologis dan psikologis yang berada di balik paradigma dominan "telah dikembangkan dari perspektif laki-laki kulit putih yang sehat dan didasarkan pada tentang studi subjek pria”(Mertens, 2005 hal.17; Mackenzie\&Knipe, 
2006). Peneliti transformatif merasa bahwa pendekatan interpretivist / konstruktivisme untuk penelitian tidak cukup menangani masalah keadilan sosial dan masyarakat yang terpinggirkan (Creswell, 2003, hal.9; Mackenzie \& Knipe, 2006).

3. Paradigma Pragmatis

Pragmatisme tidak terikat pada satu sistem filsafat atau kenyataan. Peneliti pragmatis fokus pada 'apa' dan 'bagaimana' masalah penelitian (Creswell, 2003, hal.11; Mackenzie $\&$ Knipe, 2006). Pragmatis awal "menolak gagasan ilmiah bahwa penyelidikan sosial dapat mengakses 'kebenaran' tentang dunia nyata semata-mata berdasarkan metode ilmiah tunggal" (Mertens, 2005, hal.26; Mackenzie \& Knipe, 2006). Sementara pragmatisme dipandang sebagai paradigma yang memberikan kerangka filosofis yang mendasari untuk penelitian metode campuran (Tashakkori \& Teddlie, 2003; Somekh \& Lewin, 2005; Mackenzie \& Knipe, 2006) beberapa peneliti metode campuran menyelaraskan diri secara filosofis dengan paradigma transformatif (Mertens, 2005 Mackenzie \& Knipe, 2006). Namun dapat dikatakan bahwa metode campuran dapat digunakan dengan paradigma apa pun. Paradigma pragmatis menempatkan "masalah penelitian" sebagai pusat dan menerapkan semua pendekatan untuk memahami masalah (Creswell, 2003, hal.11; Mackenzie \& Knipe, 2006).

4. Bahasa Paradigma

Saat membaca teks penelitian, kebingungan dapat terjadi ketika penulis menggunakan istilah yang berbeda untuk membahas paradigma. penggunaan bahasa yang diidentifikasi dalam berbagai teks penelitian dan dikelompokkan sesuai dengan keselarasannya dengan kelompok paradigma luas yang dibahas di atas. Sementara paradigma utama akan memiliki kerangka kerja keseluruhan yang konsisten dengan definisi yang diberikan di atas, paradigma penelitian tertentu mungkin memiliki fitur tertentu, yang membedakan mereka dari paradigma lain dalam kelompok yang sama.

Tabel 3. Paradigma Penelitian

\begin{tabular}{|c|c|c|c|c|}
\hline & $\begin{array}{l}\text { Paradigms as } \\
\text { Worldviews }\end{array}$ & $\begin{array}{l}\text { Paradigms as } \\
\text { Epistemological } \\
\text { Stances }\end{array}$ & $\begin{array}{l}\text { Paradigms as } \\
\text { Shared Beliefs in } \\
\text { a Research Field }\end{array}$ & $\begin{array}{l}\text { Paradigms as } \\
\text { Model } \\
\text { Examples }\end{array}$ \\
\hline $\begin{array}{l}\text { Mendefinisikan } \\
\text { Karakteristik }\end{array}$ & $\begin{array}{l}\text { Perspektif } \\
\text { menyeluruh } \\
\text { meliputi } \\
\text { seluruh dunia }\end{array}$ & $\begin{array}{l}\text { Ontologi, } \\
\text { epistemologi, dan } \\
\text { metodologi dari } \\
\text { filsafat } \\
\text { pengetahuan }\end{array}$ & $\begin{array}{l}\text { Kepercayaan } \\
\text { bersama tentang } \\
\text { sifat pertanyaan } \\
\text { dan jawaban di } \\
\text { bidang penelitian } \\
\text { Langsung } \\
\text { didiskusikan dan } \\
\text { disukai }\end{array}$ & $\begin{array}{l}\text { Bergantung } \\
\text { pada contoh } \\
\text { spesifik solusi } \\
\text { terbaik atau } \\
\text { khas untuk } \\
\text { masalah } \\
\text { Langsung } \\
\text { didiskusikan } \\
\text { dan disukai }\end{array}$ \\
\hline $\begin{array}{l}\text { Tempatkan } \\
\text { dalam kerja } \\
\text { Kuhn }\end{array}$ & Implisit & $\begin{array}{l}\text { Versi saat ini } \\
\text { dominan }\end{array}$ & Relatif tidak biasa & $\begin{array}{l}\text { Sangat } \\
\text { ada }\end{array}$ \\
\hline Tempatkan & Umum & Bergantung pada & Dapat dipelajari & Sangat \\
\hline
\end{tabular}




\begin{tabular}{|l|l|l|l|l|}
\hline $\begin{array}{l}\text { dalam ilmu } \\
\text { social }\end{array}$ & $\begin{array}{l}\text { digunakan } \\
\text { sebagai bukan } \\
\text { teknis } \\
\text { Mengakui } \\
\text { peran } \\
\text { pengalaman } \\
\text { pribadi dan } \\
\text { budaya dalam } \\
\text { sains }\end{array}$ & $\begin{array}{l}\text { elemen terkenal } \\
\text { dari filosofi } \\
\text { pengetahuan }\end{array}$ & $\begin{array}{l}\text { dengan meneliti } \\
\text { karya peneliti } \\
\text { yang sebenarnya }\end{array}$ & $\begin{array}{l}\text { eksplisit, } \\
\text { konkret }\end{array}$ \\
\hline Kerugian & $\begin{array}{l}\text { Terlalu luas, } \\
\text { sedikit relevansi } \\
\text { langsung dengan } \\
\text { penelitian }\end{array}$ & $\begin{array}{l}\text { Pendekatan luas } \\
\text { untuk } \\
\text { mengetahui, } \\
\text { koneksi kurang } \\
\text { langsung } \\
\text { penelitian }\end{array}$ & $\begin{array}{l}\text { Biasanya } \\
\text { kenggambarkan } \\
\text { kelompok } \\
\text { penelitian yang } \\
\text { lebih kecil, bukan } \\
\text { seluruh disiplin } \\
\text { ilmu }\end{array}$ & $\begin{array}{l}\text { Aplikasi yang } \\
\text { sangat sempit } \\
\text { dan terbatas }\end{array}$ \\
\hline $\begin{array}{l}\text { Tempatkan } \\
\text { dalam metode } \\
\text { menggabungkan }\end{array}$ & $\begin{array}{l}\text { Sedikit } \\
\text { Penggunaan } \\
\text { Eksplisit }\end{array}$ & Dampak Besar & Dampak Kecil & $\begin{array}{l}\text { Sedikit } \\
\text { penggunaan } \\
\text { eksplisit }\end{array}$ \\
\hline
\end{tabular}

Sumber : Morgan (2007)

\section{Pembahasan}

Perbedaan antara metode kualitatif dan kuantitatif dalam penelitian sosiologis lebih jelas daripada nyata. Pemisahan yang sering diartikulasikan tidak terpisah pada tingkat teoretis. Ini menunjukkan bahwa perdebatan itu lebih bersifat politis daripada teoretis atau filosofis. Beberapa garis pemikiran mendukung argumen ini dengan menawarkan bahwa perbedaan kualitatif / kuantitatif adalah konvensi daripada pemisahan epistemologis (Bryman, 1984; Hanson, 2006), bukan pemisahan yang berguna (McLaughlin, 1991; Hanson, 2006), tidak ditentukan secara paradigmatik (Smaling, 1994; Hanson, 2006), atau tidak cukup didefinisikan (Morales, 1995; Hanson, 2006). Untuk garis pemikiran ini saya menambahkan analisis meta-teoretis dari beberapa masalah yang biasanya digunakan untuk membuat kesenjangan subjektivitas kuantitatif / kualitatif versus objektivitas, sistematisasi, kuantifikasi dan generalisasi. Saya berpendapat bahwa masalah ini tidak dapat dibedakan pada tingkat epistemologis.

Debat kuantitatif / kualitatif dapat dilihat sebagai refleksi dari masalah dengan bagaimana sains dan metodologi positivis dipandang dari luar. Ini muncul dalam apa yang Bryman telah berargumentasi secara efektif adalah kebingungan teknik dan metode (Bryman, 1984; Hanson 2006), Masalah utama adalah pertanyaan tentang objek dan bagaimana objek berhubungan dengan subjektivitas. Meskipun positivisme sering dilemparkan sebagai model objek yang menyangkal subjektivitas, justru sebaliknya dapat diperdebatkan. 


\section{Pemisahan Yang Tidak Memisahkan Metode Kualitatif Versus Kuantitatif}

Tinjauan penulisan tentang metodologi dalam sosiologi menunjukkan beberapa masalah yang sering digunakan untuk memisahkan dan mendefinisikan metode kualitatif versus kuantitatif. Saya telah mengelompokkan ini dalam empat tema: subjektivitas versus objektivitas, sistematisasi, kuantifikasi dan generalisasi. Saya menyadari bahwa tema-tema ini kehilangan banyak detail dalam mewakili lebih dari empat dekade kerja, tetapi merasa bahwa mereka menangkap beberapa tren utama. Setelah menguraikan setiap masalah, saya menyajikan argumen mengapa itu bukan pemisahan yang valid. (Hanson, 2006)

\section{Subjektivitas Versus Objektivitas}

Kemampuan reflektif diri manusia dan bagaimana ia masuk ke dalam proses pengumpulan data manusia baik dari manusia maupun oleh manusia telah diakui dalam filsafat ilmu secara umum dan metode kualitatif dan kuantitatif dalam sosiologi. Namun, sosiolog kualitatif atau kritis cenderung menganggap sosiolog kuantitatif dan ilmuwan alam atau fisik sebagai fokus pada obyektivitas terhadap pengabaian subjektivitas baik itu individu, interpersonal, atau politik. (Hanson, 2006)

Dalam praktiknya, pencarian objektivitas adalah upaya untuk menghasilkan bahasa yang sama yang akan memungkinkan para cendekiawan untuk berbicara satu sama lain dengan mengetahui bahwa satu meter adalah satu meter, atau satu ons adalah ons yang diukur pada titik tengah meniskus dalam sebuah tabung. Subjektivitas dan obyektivitas tidak bertentangan dalam praktek, tetapi lebih seperti dialektika Hegel di mana Anda tidak dapat memiliki satu tanpa yang lain. Ini diakui dalam "standar emas" penelitian dalam ilmu alam, sosial ekonomi, fisik dan medis, uji klinis acak tersamar ganda. Baik peneliti maupun peserta penelitian tidak tahu siapa yang sedang diuji dan apa, oleh karena itu memiliki kendali atas hasil. Ini adalah pengakuan langsung akan pentingnya subjektivitas manusia. (Hanson, 2006)

\section{Kesimpulan}

Penulis menyimpulkan bahwa perbedaan antara pendekatan kualitatif dan kuantitatif tampaknya tidak jelas, dan bermasalah. Berkontribusi pada hal ini adalah bahwa apa yang dianggap sebagai fitur penelitian kualitatif dan kuantitatif tumpang tindih sebagian besar (lihat Allwood 2002). Alternatif yang lebih baik untuk mengklasifikasikan penelitian dan metode penelitian dalam hal kualitatif dan kuantitatif, Saya juga menyampaikan, untuk membahas pro dan kontra dari berbagai metode penelitian pada tingkat yang lebih konkret dan spesifik, mungkin yang terbaik dalam konteks jenis masalah penelitian tertentu. Selain 
itu, akan lebih baik untuk tidak mendefinisikan penelitian kualitatif berbeda dengan gagasan umum tentang penelitian kuantitatif. Sebaliknya mungkin lebih konstruktif untuk mencoba mengidentifikasi dan kemudian memberi label pada versi berbeda dari penelitian kualitatif dan kuantitatif.

Salah satu alasan mengapa perbedaan masih digunakan oleh orang-orang yang bertanggung jawab untuk kursus metodologi dan di penerbit yang bertanggung jawab atas seri buku mungkin karena pemikiran yang tersirat oleh perbedaan antara penelitian kualitatif dan kuantitatif memberikan kesan bahwa perbedaan itu mudah dipahami. Namun, seperti yang coba tunjukkan dalam tulisan ini kesan ini cukup menyesatkan. Ada banyak cara yang mungkin dan menarik untuk membagi pendekatan penelitian, tidak ada yang perlu perlu dilihat sebagai lebih mendasar daripada yang lain. Pemisahan pendekatan penelitian menjadi kualitatif dan kuantitatif sebenarnya merupakan undangan untuk pemikiran sederhana tentang masalah yang rumit dan dengan demikian dapat menghambat pengembangan pemahaman tentang masalah-masalah filosofis dan metodologi penelitian. Dan yang harus ditekankan bahwa metode hanya alat untuk operasi penelitian, maka kita menggunakan metode kuantitatif atau kualitatif sesuai dengan kebutuhan masalah penelitian.

\section{Daftar Pustaka}

André Queirós, Daniel Faria, Fernando Almeida. (2017). Strengths And Limitations Of Qualitative And Quantitative Research Methods. European Journal Of Education Studies. DOI: 10.5281/zenodo.887089. Volume 3 Issue 92017. ISSN: 2501 - 1111. ISSN-L: $2501-1111$.

BARBARA HANSON. (2006). Wither Qualitative / Quantitative ? : Grounds for Methodological Convergence. Quality \& Quantity (2008) 42:97-111 (C) Springer 2006. DOI 10.1007/s11135-006-9041-7.

Carl Martin Allwood. (2012). The Distinction Between Qualitative And Quantitative Research Methods Is Problematic. Qual Quant (2012) 46:1417-1429. DOI 10.1007/S11135-011-9455-8.

Chris Barnham. (2016). Quantitative And Qualitative Research Perceptual Foundations. International Journal Of Market Research Vol. 57 Issue 6.

David L. Morgan. (2007). Paradigms Lost and Pragmatism Regained: Methodological Implications of Combining Qualitative and Quantitative Methods. Journal of Mixed Methods Research 2007. 1: 48. DOI: 10.1177/2345678906292462. 
Gerhard Kleining \& Harald Witt. (2001). Discovery as Basic Methodolog of Qualitative and Quantitative Research. Forum: Qualitative Social Research. Volume 2, No. 1, Art. 16 February 2001.

JOANNA E. M. SALE, LYNNE H. LOHFELD And KEVIN BRAZIL. (2002). Revisiting the Quantitative-Qualitative Debate: Implications for Mixed-Methods Research.

Kaya Yilmaz. (2013). Comparison of Quantitative and Qualitative Research Traditions : epistemological, theoretical, and methodological differences. European Journal of Education, Vol. 48, No. 2, 2013.

Looi Theam Choy. (2014). The Strengths and Weaknesses of Research Methodology: Comparison and Complimentary between Qualitative and Quantitative Approaches. IOSR Journal Of Humanities And Social Science (IOSR-JHSS) Volume 19, Issue 4, Ver. III (Apr. 2014), PP 99-104. e-ISSN: 2279-0837, pISSN: 2279-0845.

Md. Shidur Rahman. (2017). The Advantages and Disadvantages of Using Qualitative and Quantitative Approaches and Methods in Language "Testing and Assessment" Research: A Literature Review. Journal of Education and Learning; Vol. 6, No. 1; 2017. ISSN 1927-5250. E-ISSN 1927-5269.

Noella Mackenzie and Sally Knipe. (2006). Research dilemmas: Paradigms, methods and methodology. Issues in Educational Research, 16(2), 2006.

Patrik Aspers and Ugo Corte. (2019). What is Qualitative in Qualitative Research. Qualitative Sosiology. DOI:org/10.1007/s11133-019-9413-7.

Rutberg, S., \& Bouikidis, C.D. (2018). Focusing on the fundamentals : A simplistic differentiation between qualitative and quantitative research. Nephrology Nursing Journal, 45(2), 209-212.

Skrzek-Lubasinska, M., and Szaban, J., M. (2018). Nomenclature and harmonised criteria for the self-employment categorisation: An approach pursuant to a systematic review of the literature. European Management Journal

Thomas P. Wilson. (1986). Qualitative "Versus" Quantitative Methods In Social Research. Departement of Sociology, Universitas Of California at Santa Barbara.

Todd D. Jick. (1979). Mixing Qualitative and Quantitative Methods: Triangulation in Action. Administrative Science Quarterly, Vol. 24, No. 4, Qualitative Methodology. Dec., 1979. pp. 602-611. 